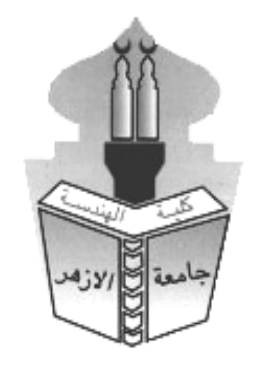

\title{
FEASIBLITIES of ENERGY SAVING of AIR-CONDITIONED BUILDINGS in KUWAIT
}

\author{
Essa S. Bin Essa and Mohammad A. Alobaid \\ The public authority for applied education and training, Construction Training Institute \\ Mechanical Works Department
}

\begin{abstract}
Energy management of heating, ventilating and air conditioning (HVAC) systems is one of the main factors in environmentally building design. In Kuwait, Air conditioning equipments consume about seventy percents of the energy consumption in summer. This paper proposes optimization approach for energy management in HVAC systems. It investigates experimentally and theoretically the effect of some operating factors as condensing pressure, ambient temperature, solar heat gain, building specifications..etc, on the HVAC energy consumption. The cooling load consumption during the summer in the hot and humid areas of Kuwait is estimated along with the actual electrical energy consumption.
\end{abstract}

\section{Keywords: Energy savings; HVAC; Energy Management}

\section{NOMENCLATURE}

$\begin{array}{ll}A_{D} & \text { Surface area of doors, } \mathrm{m}^{2} \\ A_{G} & \text { Surface area of glasses, } \mathrm{m}^{2} \\ A_{W} & \text { Surface area of walls, } \mathrm{m}^{2} \\ C & \text { Capacity of air conditioning system } \\ D & \text { Diffusive radiation } \\ F & \text { Lighting coefficient } \\ h_{j} & \text { Heat transfer coefficient, W/m } / \mathrm{m}^{2} \mathrm{~K} \\ h_{i r} & \text { Heat transfer coefficient of air under the roof, } \mathrm{W} / \mathrm{m}^{2} \mathrm{~K} \\ I & \text { Intensity of direct sun radiation } \mathrm{W} / \mathrm{m}^{2} \\ m & \text { Mass flow rate of air, kg/s } \\ N_{R} & \text { No. of external roofs } \\ N_{W} & \text { No. of external walls } \\ N_{P} & \text { Net power, } \mathrm{kW} \\ P & \text { Power consumption for lighting, W } \\ Q_{R a d} & \text { Rate of heat absorption per surface area of black body, W/m } \\ Q_{L} & \text { Latent heat, } \mathrm{kW} \\ Q_{S} & \text { Sensible heat, } \mathrm{kW} \\ T_{r i} & \text { Temperature of interior surface of the roof. }{ }^{\circ} \mathrm{C} \\ T_{W i} & \text { Temperature of interior surface of the wall, }{ }^{\circ} \mathrm{C}\end{array}$




$\begin{array}{ll}T_{a i} & \text { Temperature of interior air, }{ }^{\circ} \mathrm{C} \\ T_{G} & \text { Glass temperature, }{ }^{\circ} \mathrm{C} \\ T_{D} & \text { Door temperature, }{ }^{\circ} \mathrm{C} \\ V^{\prime} & \text { Air volume flow rate, } \mathrm{m}^{3} / \mathrm{hr} \\ W_{i} & \text { Humidity of inlet air, } \mathrm{kg} \mathrm{h}_{2} \mathrm{O} / \mathrm{kg} \text { d.a. } \\ W_{o} & \text { Humidity of outlet air, } \mathrm{kg} \mathrm{h}_{2} \mathrm{O} / \mathrm{kg} \text { d.a. }\end{array}$

Greek Symbols

$\alpha$

$\rho$

$\lambda$

Absorption coefficient

Air density, $\mathrm{kg} / \mathrm{m}^{3}$

$\tau_{I}$

Latent heat of vaporization

Transmission coefficient of glass for direct solar radiation

$\tau_{D}$

Transmission coefficient of glass for diffuse solar radiation

\section{INTRODUCTION}

Costs for energy used in building operations have become such a significant expense that it is necessary that they be kept to a minimum level. This requires a through analysis of energy use and conversion in $\mathrm{A} / \mathrm{C}$ design, installation, and operation. In must be recognized that use of energy studies is no optional on the part of the $\mathrm{A} / \mathrm{C}$ designer, contractor, or operating personal. Air conditioning systems are widely used for thermal comfort during extreme weathers. Condensers of such systems may be water - cooled or air cooled. In the case of air cooled condensers, ambient temperature, relative humidity, wind directions has a great effect on the performance of the unit. In hot, arid areas, such as Kuwait ambient temperature may reach $55^{\circ} \mathrm{C}$ under shade. Such a high ambient temperature decreases the performance of the unit and thereby increases the power required for cooling. It has been observed that an increase in ambient temperature from $35^{\circ} \mathrm{C}$ to $50^{\circ} \mathrm{C}$ can decrease the performance of the $\mathrm{HVAC}$ unit by about $20 \%$.

Extensive research is recorded in the literature about optimization of energy consumption in air-conditioned buildings. Windows have a significant role with critical responsibility in connecting the indoor environment of building to the outdoor. Buildings with large areas of glazing, incur excessively high electrical demands. One way of reducing the magnitude of this demand is through better window design. It has been shown that use of colored and coated (thermal insulated) glazing [1,2] double or triple layer glazing units[3], smart windows [4], choosing the optimum sized windows[5] are the ways to reduce cooling load of the building contributed by the windows.

For different usages of buildings, the requirement of dry bulb temperature and humidity levels may be different. In hot climates, for the buildings used for living purposes, humidity level up to $70-80 \%$ and dry bulb temperature $30^{\circ} \mathrm{C}$ may be tolerable. But for buildings using electronic gadgets (computer rooms, telephone exchanger, etc) the humidity levels should not be more than 50-60\%, though higher values of dry bulb temperatures may be acceptable. In such cases, the use of indirect evaporative cooler (IEC) promises to be a cost-effective option. Moreover, since DEC are not effective in humid climates, the use of IEC is advisable[6,7,8]. It has been experimentally proved by ElFahed et al [9], that using evaporative cooling on a $10 \mathrm{TR}$, package air conditioning unit can decrease the condenser air inlet temperature by $23-30 \%$, and hence, increase the COP $35-42 \%$. The energy saving reached to $26 \%$.

Through many investigators $[10,11]$ have given similar coolers in different climates. For variable (periodic) conditions to which the building envelope is expected, the thermal load into the building is determined by the thermal conductivity, specific 
thermal capacity and thickness of each layer of the components of the building envelope. For estimating periodic thermal loads of the different components of the building envelope, admittance method of Sodha et al. [12], has been used. The performance of DECs and IECs coupled to the buildings has been evaluated for: hotdry climate, warm -humid climate and composite climate. A mathematical model has been developed to evaluate the relative thermal performance of a building coupled with an indirect or direct evaporative cooler $[13,14]$. The evaluation of existing cooling systems for reducing cooling power consumption was investigated by Hatamipour et al. [15]. They proved that the use of double glazed windows, light colored walls and roofs.

Measurements of heat exchanger performance are called performance evaluation criteria (PEC), which focus on the comparisons of the heat exchanger performance on one fluid side of the heat exchanger- the refrigerant side or the air side in the air conditioning applications ( Dejong et al. 1997). Bergles et al; (1974), Webb (1981) and Cowell (1990) presented energy - based PEC. In research by DeJong et al (1997), simplified entropy - based PEC model is developed and applied to condenser of an air conditioning unit to assess the air side performance and accordingly, size of the condenser. In this application, the heat load, and condenser inlet temperature were set to constant values. Effect of air flow rate on the performance of the condenser has been investigated for different areas and flow lengths. A same study of Ref. [9] was applied on 2.8 TR split unit by Waly et al (2005).

This paper investigates directly feasibilities of improving HVAC systems energy consumptions especially service in hot areas. A simple computer program is designed to analysis the results of cooling load power consumption during summer seasons in Kuwait. Suggestions some rules for reducing the cooling load power consumption is concluded.

\section{CLIMATE OF KUWAIT}

Kuwait is a hot and humid country, it is a small coastal country has harsh and extreme weather conditions during the long summer-period that spans over seven months from April to October. The daytime temperatures often exceed $49^{\circ} \mathrm{C}$, and the daily average is well over $36^{\circ} \mathrm{C}$ for the most summer season. As a result, air-conditioning $(\mathrm{A} / \mathrm{C})$ accounts for $50 \%$ of national electricity consumption and $70 \%$ of power plant capacity. Nine months in year, Mar to November are the hot months in the Kuwait area, and Jun, July, and August are the months of harsh condition of heat. As shown in Fig. (1).

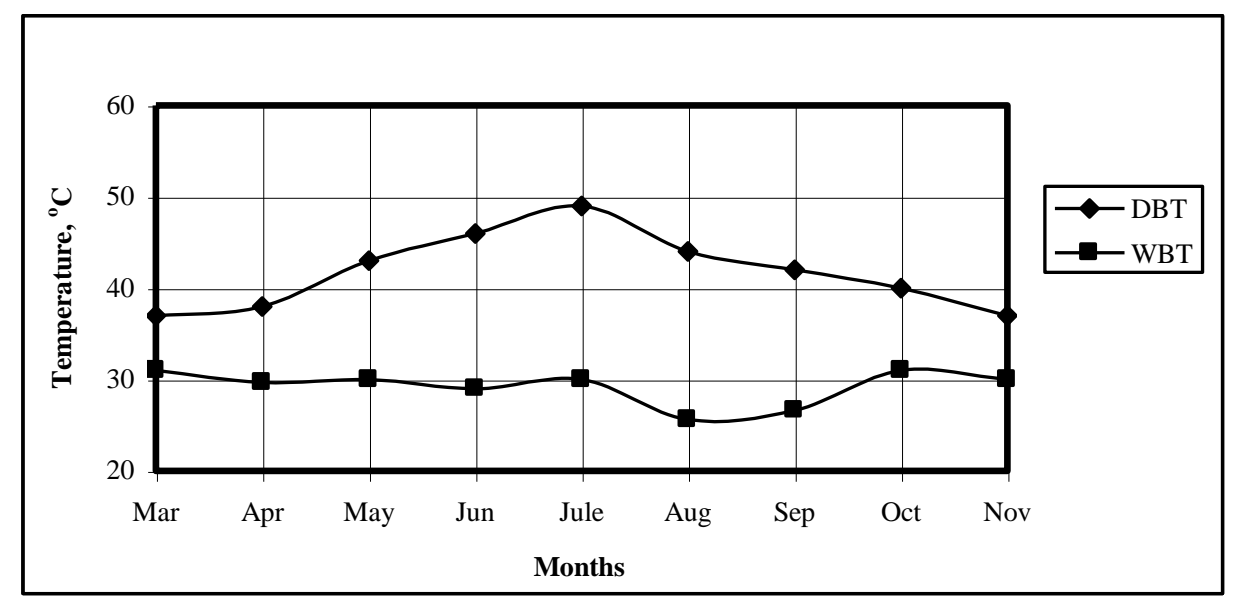

Figure 1: Monthly average dry and wet bulb temperatures history in Kuwait in 2006 


\section{COOLING LOAD ESTIMATION}

For sizing the air conditioning system for a building, the cooling load of the building might be calculated. The air inside a building receives heat from a number of sources during the cooling season. If the temperature and humidity of the air are to be maintained at a comfortable level, this heat must be removed. The amount of heat that must be removed is called the cooling load. The cooling load must be determined because is the basis for selection of the proper size of air conditioning equipment and distribution system.

The cooling load is not always equal to the amount of heat received from the space at a given time. This difference is a result of the heat storage and time lag effects. Of the total amount of heat entering the building at any instant, only a portion of it heats the room air immediately; the other part (the radiation) heats the building mass-the roof, walls, floors, and furnishings. This is the heat storage effect. Only at a later time does the stored heat portion contribute to heating the room air. The room cooling load is the rate at which heat must be removed from the room air to maintain it at the design temperature and humidity. The thermal storage effect and resulting time lag cause the cooling load to often be difference in value from the entering heat called instantaneous heat gain.

The heat gain components that contribute to the room cooling load consist of the following: Conductions through exterior walls, roof, and glass, conduction through interior partitions, ceilings, and floors, solar radiation through glass, lighting, people, equipment, and heat from infiltration of outside air through openings. It is convenient to arrange these heat gains into two groups: those from external sources outside the room, and those internally generated. It is seen that first three items are external heat gains, and other items are internal heat gains. Infiltration can be considered as a separate class. It is also convenient to arrange the heat gains into a different set of two groups: sensible and latent heat gains. Sensible heat gains result in increasing the air temperature; latent heat gains are due to addition of water vapour, thus increasing humidity. The cooling load is calculated directly by considering into account the effect of following parameters according to Eq. (1).

$$
\mathrm{Q}_{\mathrm{C}}=\mathrm{Q}_{\mathrm{T}}+\mathrm{Q}_{\mathrm{S}}+\mathrm{Q}_{\mathrm{I}}+\mathrm{Q}_{\mathrm{A}}
$$

Where QC is the total cooling capacity, QT is the cooling load due to heat transfer from exterior walls and envelopes, QS is the cooling load due to sun radiation transmitted from windows or doors, QI is the cooling load due to heat generated by appliances, persons, etc. and QA is the cooling load due to air flow into the building (sensible and latent heat). For each of above items some well-known equations are developed and can be used with care. Heat transmitted from exterior walls and envelopes is found from Eq. (2).

$$
\begin{aligned}
Q_{T}= & h_{i} \sum_{j=1}^{N_{W}}\left[A_{w j}\left(T_{w i}-T_{f i}\right)_{j}+A_{G j}\left(T_{G}-T_{f i}\right)_{j}+A_{D j}\left(T_{D}-T_{f i}\right)_{j}\right] \\
& +h_{i R} \sum_{j=1}^{N_{R}} A_{R j}\left(T_{R i}-T_{f i}\right)_{j}
\end{aligned}
$$

The wall temperature must be calculated mathematical modeling of the unsteady state heat transfer in the wall. It depends on radiation intensity, variations of external air temperature and accumulation of inside the wall. Rate of heat absorption due to radiation on black bodies is calculated by Eq. (3).

$$
\mathrm{Q}_{\mathrm{rad}}=\alpha(1+\mathrm{D})
$$


A major part of cooling load is transmissions of sun radiation through windows of buildings. Cooling load due to this phenomenon is calculated by using Eq. (4).

$$
\mathrm{Q}_{\mathrm{S}}=\tau_{\mathrm{I}} \mathrm{I}+\tau_{\mathrm{D}} \mathrm{D}
$$

Internal cooling load is mainly due to heat generated by lighting system, person in the building and home appliances. So, internal cooling load is calculated by using Eq. (5).

$$
\mathrm{Q}_{\mathrm{I}}=\mathrm{Q}_{\text {Light }}+\mathrm{Q}_{\text {Person }}+\mathrm{Q}_{\text {Appliances }}
$$

Heat generated by lighting system is calculated by using Eq. (6).

$$
\mathrm{Q}_{\text {lighting }}=\mathrm{P} \times \mathrm{C}_{\mathrm{L}}
$$

Heat generated by persons and appliances is found from tables of Ref. [16]. Whereas, the heat gain from people is composited of two parts, sensible heat and the latent heat resulting from perspiration. Some of the sensible heat may be absorbed by the storage effect, but not the latent heat. The Eq. (7) is used as following:

$$
\begin{aligned}
\mathrm{Q}_{\text {people }} & =\mathrm{Q}_{\text {sensible }}+\mathrm{Q}_{\text {Latent }} \\
& =\mathrm{n}\left(\mathrm{q}_{\mathrm{s}} \mathrm{C}_{\mathrm{P}}+\mathrm{q}_{1}\right)
\end{aligned}
$$

where, $\mathrm{n}$ is the number of persons, and $\mathrm{C}_{\mathrm{P}}$ is people coefficient. If the air conditioning system is shut down at night, $\mathrm{C}_{\mathrm{P}}=1$. The heat gain from equipment may sometimes be found directly from the manufacturer or the nameplate data, with allowance for intermittent and latent heat. Some values of heat output for typical appliances are taken from [16]. The proportion of heat generated that is gained by the air-conditioned space depends on whether the motor and driven load are both in the space or only one them is taken from Ref. [16]. The Eq. (8) can be used.

$$
\mathrm{Q}_{\text {appliances }}={\mathrm{P} \times \mathrm{C}_{\mathrm{a}}}
$$

The infiltration of air through cracks around windows or door results in both a sensible and latent heat gain to the rooms. Also, most summer air conditioning systems have mechanical ventilation using some outside air, which reduces or eliminates infiltration by creating a positive air pressure with a building. Ventilation air is not a load on the building, but is a load on the central cooling equipment. The equations for determining the sensible and latent cooling loads from ventilation air are found as:

$$
\begin{aligned}
& \mathrm{Q}_{\mathrm{S}}=1.1 \times \mathrm{CFM} \times\left(\mathrm{T}_{\mathrm{o}}-\mathrm{T}_{\mathrm{i}}\right) \\
& \mathrm{Q}_{\mathrm{L}}=0.68 \times C F M \times\left(\mathrm{W}_{\mathrm{o}}^{\prime}-\mathrm{W}_{\mathrm{i}}^{\prime}\right)
\end{aligned}
$$

So, the cooling load due to outside air flow $\left(\mathrm{Q}_{\mathrm{A}}\right)$ is calculated by use of Eq. (11).

$$
\mathrm{Q}_{\mathrm{A}}=\mathrm{Q}_{\mathrm{S}}+\mathrm{Q}_{\mathrm{L}}
$$

For CFM is not known, so it can be used the Eqs. $(12,13)$ for determining sensible and latent heat due to outside air flow.

$$
\begin{aligned}
& \mathrm{Q}_{\mathrm{S}}=\mathrm{V}^{\prime} \rho \mathrm{Cp}\left(\mathrm{T}_{\mathrm{o}}-\mathrm{T}_{\mathrm{i}}\right)=\mathrm{m}^{\prime} \mathrm{Cp}\left(\mathrm{T}_{\mathrm{o}}-\mathrm{T}_{\mathrm{i}}\right) \\
& \mathrm{Q}_{\mathrm{L}}=\mathrm{V}^{\prime} \rho\left(\mathrm{W}_{\mathrm{i}}-\mathrm{W}_{\mathrm{o}}\right) \lambda
\end{aligned}
$$

The capacity of air conditioning system is calculated for maximum cooling load, by a trial and error procedure based on the above equations for various times of days in peak loads of the day. Use Eq. 14.

$$
C_{A C}=\frac{Q_{\text {Cooling }}}{\rho C_{P}\left(T_{F_{O}}-T_{A C}\right)}
$$

\section{PROCEDURE \& MEASUREMENTS}

The peak load period for electrical power consumption usually occurs in the second mid of Jun to the first mid of August. In order to investigate the state of energy 
consumption during peak load period, different cases of conditioned buildings were studied. The annual power consumption of each building was determined by recording the maximum total power consumption of the building during peak load period, and then subtracting from it the power consumption of all non-air conditioning electrical appliances in use in the building. By taking the average power consumption of the buildings with the same applicability and assuming the same behavior for power consumption of buildings with similar application in the province, the total cooling (airconditioning) power consumption for the province was estimated.

\section{SELECTED BUILDINGS SPECIFICATIONS}

Five different air-conditioned buildings were selected as samples in the study. The buildings are Farawania hospital, primary school of grails, health center, building, 23, CTS, and building 102, CTS. The specifications of selected buildings are obtained and used in calculations. Samples of building and cooling load items specifications are given Tab. 1, 2.

Table 1: The Farwaniya hospital building specifications

\begin{tabular}{|l|l|}
\hline Parameter & Description \\
\hline Shell wall & $\begin{array}{l}\text { Hollow concrete blocks (sand and gravel agg.), while cement plaster as } \\
\text { exterior furnish, thickness }=28 \mathrm{~cm}, \mathrm{k}=1.5 \mathrm{~W}\left(\mathrm{~m} .{ }^{\circ} \mathrm{C}\right), \rho=1000 \mathrm{~kg} / \mathrm{m} 3, \\
\text { solar heat absorption }=0.56\end{array}$ \\
Roof & $\begin{array}{l}\text { Hollow concrete blocks, thickness }=28 \mathrm{~cm}, \mathrm{k}=1.4 \mathrm{~W}\left(\mathrm{~m} .{ }^{\circ} \mathrm{C}\right), \rho=1000 \\
\mathrm{~kg} / \mathrm{m} 3, \text { solar heat absorption }=0.56 .\end{array}$ \\
& $2 \mathrm{~cm}$ gypsum plaster, light green color \\
Interior wall & Aluminum frames, $1.6 \mathrm{x} 0.8 \mathrm{~m}$ \\
Windows & Ordinary glass, $4 \mathrm{~mm}$ thick \\
Glass type & Vertical screen, light brown color \\
Curtain & $\mathrm{T}_{\max }=48^{\circ} \mathrm{C}, \mathrm{T}_{\min }=38^{\circ} \mathrm{C}, \mathrm{T}_{\mathrm{WB}}=32^{\circ} \mathrm{C}$ \\
Air temperature & $4500 \mathrm{~m}^{3} / \mathrm{h}$ \\
Air rate & 630 persons in building \\
People & Lighting heat load $=55 \mathrm{w} / \mathrm{m}^{2}$ \\
Lighting & Appliances heat load $1262 \mathrm{hp}$. \\
Equipment & $105000 \mathrm{~m}^{2}$ \\
Built over area &
\end{tabular}

Table 2: Used electrical appliances in the Farwaniya hospitals

\begin{tabular}{|l|c|c|c|}
\hline Appliance & Number & $\begin{array}{c}\text { Unit power } \\
\text { Consumption }(\mathrm{w})\end{array}$ & $\begin{array}{c}\text { Total power } \\
\text { consumption }(\mathrm{kW})\end{array}$ \\
\hline RAC chilled 22000 & 8 & 84000 & 672 \\
RAC package 18000 & 12 & 3500 & 42 \\
RAC split 24000 & 6 & 2900 & 17.4 \\
RAC Window 18000 & 5 & 2300 & 11.5 \\
Lighting & 6000 & 35 & 210 \\
$\quad$ Fluorescent & 126 & 125 & 15.75 \\
$\quad$ Ballasant & 80 & 450 & 36 \\
+PCs & 12 & 1500 & 18 \\
Cookers & 34 & 350 & 1.375 \\
Refrigerators & 5 & 275 & 10 \\
Water coolers & & & 1153.025 \\
Another applications & & & \\
Total & & &
\end{tabular}




\section{RESULTS \& DISCUSSION}

The predicated cooling load of the selected buildings is estimated by using a simple computer program. The installed cooling system capacity is compared with the predicted cooling load. The results are summarized in Table 3. As seen in the Tab. 4, whereas selecting, installing and maintaining windows equipments and accessories can help for reducing cooling, heating, and lighting costs. They can also be major sources of heat gain to air-condition in the summer. Also, when air leaks around window, energy is wasted. Energy is also transferred through the centers, edges, and frames of window. Eliminating or reducing theses paths of heat flow can greatly improve the energy efficiency of windows and, ultimately, of homes. Several windows design is testing and simulated in the results.

Table 3: Comparison between installed and predicted cooling load.

\begin{tabular}{|l|c|c|}
\hline Buildings & $\begin{array}{c}\text { Installed Cooling } \\
\text { Capacity, kW }\end{array}$ & $\begin{array}{c}\text { Predicted cooling } \\
\text { Capacity, kW }\end{array}$ \\
\hline Farwaniya hospital & 10750 & 9800 \\
Farwaniya primary school & 254 & 268 \\
Farwaniya health center & 210 & 195 \\
Governmental Building 102 & 10 & 7.8 \\
Governmental CTS, Building 23 & 2500 & 1980 \\
\hline
\end{tabular}

The data of governmental building 23, CTS (Department of Mechanical Power \& Refrigeration) is tabulated in details in Tab. 4, for other buildings the results is summarized in Tab. 5. It was assumed that the coefficient of performance of cooling system is fixed and considered as 3.75 for all studied buildings. It was found that in most cases, the predicted cooling load which estimated theoretically by using a simple computer program is less than the installed ones

Table 4: Results of governmental building N0. 23 CTS in details.

\begin{tabular}{|c|c|c|c|c|c|}
\hline Case & $\begin{array}{c}\text { Sensible } \\
\text { Cooling } \\
\text { Load }(\mathrm{kW})\end{array}$ & $\begin{array}{c}\text { Latent } \\
\text { Cooling } \\
\text { Load }(\mathrm{kW})\end{array}$ & $\begin{array}{c}\text { Total } \\
\text { Cooling } \\
\text { Load }(\mathrm{kW})\end{array}$ & $\begin{array}{c}\text { Peak } \\
\text { Load } \\
\text { Consumption }(\mathrm{kW})\end{array}$ & $\begin{array}{c}\text { Energy } \\
\text { Reduction } \\
(\mathrm{kW}, \%)\end{array}$ \\
\hline 1 & 1560 & 520 & 2080 & 1980 & - \\
2 & 1549 & 520 & 2069 & 1950 & 1.5 \\
3 & 1502 & 520 & 2022 & 1920 & 3.0 \\
4 & 1423 & 520 & 1943 & 1840 & 1.0 \\
5 & 1335 & 520 & 1855 & 1765 & 13.8 \\
6 & 1290 & 520 & 1810 & 1705 & 14.9 \\
7 & 1255 & 520 & 1775 & 1790 & 9.5 \\
8 & 1210 & 520 & 1730 & 1725 & 12.9 \\
9 & 1180 & 520 & 1700 & 1644 & 22.0 \\
10 & 1150 & 520 & 1670 & 1589 & 20.9 \\
11 & 1090 & 520 & 1610 & 1566 & 24.7 \\
12 & 1020 & 520 & 1540 & 1490 & 11.1 \\
13 & 970 & 520 & 1480 & 1760 & 7.3 \\
14 & 1460 & 520 & 1980 & 1835 & 13.6 \\
15 & 1380 & 520 & 1900 & 1710 & 28.3 \\
16 & 1490 & 520 & 2010 & 1420 & 20.9 \\
17 & 1100 & 520 & 1620 & 1565 & \\
18 & 1420 & 423 & 1843 & & \\
\hline
\end{tabular}

It is recommended for properly, installing, fixed - pane windows are airtight and inexpensive and can be custom designed for a wide variety of applications. Also, 
manufacturers usually represent the energy efficiency of windows in terms of their Uvalues (conductance of heat) or their R-values (resistance to heat flow). If a window's $\mathrm{R}$-value is high, it will lose less heat than one with a lower R-value. Conversely, if a window's U-value is low, it will lose less heat than one with a higher U-value. In other words, $\mathrm{U}$-values are reciprocals of $\mathrm{R}$-values ( $\mathrm{U}$-value $=1 / \mathrm{R}$-value). Most window manufacturers use $\mathrm{R}$-values in rating their windows. The type of glazing material (glass, plastic, treated glass), number of layers of glass, the size of air space between the layers of glass, the thermal resistance or conductance of the frame and space materials and the tightness of the installation affect the R-value of the window.

Table 5: Summarized other studied building results

\begin{tabular}{|c|c|c|c|c|}
\hline Cases & $\begin{array}{c}\text { Hospital } \\
\text { energy Saving } \\
\%\end{array}$ & $\begin{array}{c}\text { School } \\
\text { energy Saving } \\
\%\end{array}$ & $\begin{array}{c}\text { Health center } \\
\text { energy Saving } \\
\%\end{array}$ & $\begin{array}{c}\text { Building 102 } \\
\text { energy Saving } \\
\%\end{array}$ \\
\hline 1 & - & - & - & - \\
2 & 2.8 & 1.8 & 1.2 & 0.89 \\
3 & 2.8 & 2.4 & 2.4 & 1.9 \\
4 & 8.8 & 6.2 & 6.8 & 5.0 \\
5 & 7.3 & -9.6 & 10.8 & 12.8 \\
6 & 11.2 & 1.6 & 13.8 & 11.8 \\
7 & 16.3 & -2.6 & 16.9 & 14.1 \\
8 & 12.7 & 8.4 & 9.5 & 10.5 \\
9 & 14.9 & 10.5 & 12.9 & 14.9 \\
10 & 16.8 & 13.5 & 19.1 & 13.6 \\
11 & 19.9 & 13.2 & 22.0 & 21.9 \\
12 & 21 & 18.2 & 19.9 & 25 \\
13 & 23.2 & 17.5 & 12.3 & 10.2 \\
14 & 8.9 & 15.6 & 9.6 & 7.9 \\
15 & 5.2 & 7.3 & 14 & 12.9 \\
16 & 2.9 & 13.6 & - & 19.9 \\
17 & - & - & 29.3 & 4.3 \\
18 & 32.5 & 23 & & \\
\hline
\end{tabular}

Traditionally, clear glass has been the primary material available for window panes in homes. However, in recent years, the market for glazing-or cutting and fitting window panes into frames-has changed significantly. Now several types of special glazing are available that can help control heat loss. Movable insulation, such as insulating shades, shutters, and drapes, can be applied on the inside of windows to reduce heat loss in the winter and heat gain in the summers. Shading devices, such as winnings, exterior shutters, or screens, can be used to reduce unwanted heat gain in the summer. It is noted for hospital and health center the ventilation load part is high, so there is a high saving in that items. Also it could not carry and modification or measurements for school, health center, and hospital so, there is no any data for condensing temperature effect those buildings. The type of selecting light of building plays an important role in the energy consumption in buildings. As stated in Tables 4, and 5, the biggest saving in energy consumption of building CTS, 23 and 102, is case No. seventeen. Whereas, this case studies the effect of decreasing condensing temperature of condensing unit of HVAC systems. It used indirect evaporative cooling around condensing units of air conditioning systems. Reducing heat loss or gain in homes often includes either improving existing windows or replacing them. Low cost options available for improvement heat loss form air-conditioned buildings must be use-efficient-energy materials. Different combinations of frame style frame material and glazing can yield very different results when weighting energy efficiency and cost. 


\section{CONCLUSION}

According to the results of listed in Tabs. 4, 5, the following items can be taken in account for energy saving in air conditioned buildings in Kuwait.

1. The additional condenser evaporative cooler system is an alternative energyconservation proposition to improve the performance HVAC package units.

2. The cooler system offers maximum reduction in consumption electrical power and peak power demand as its best performance coincides with the hour of peak cooling capacity and peak power demand.

3. Use of external shading screen, external curtain and implanting shading trees or studs near the windows are very effective for very hot and humid climates conditioning.

4. Use the double glazed windows, light color walls and roofs, and use of insulation in walls and roofs, up to $45 \%$ reduction in the cooling load can be reached.

5. The size of window must be reduced to the required level for day lighting. The windows must be installed in the upper part of the wall near the roof, with the least width.

6. The buildings must be constructed across to the direction of wind.

7. The comfort temperature in the building must be adjustable for each room, and it must be adjusted to the maximum possible value for buildings in night and at nonoccupied cases.

8. The decreasing the condensing temperature as possible of HVAC condensing units can play important role to decrease energy consumption of conditioned buildings.

9. Decreasing glass are in walls generally decreased the energy consumption of buildings.

10. Use saved lamps and optimization lights in the buildings can be save energy consumption of buildings.

11. Decreasing the fresh air amount (Ventilation rate) is very good method to save electrical energy consumption especially during the peak hours in summer.

12. During peak summer months of Kuwait, (Jun, Jule and Augest), it is very important to put fans of HVAC system position, AUTO from Thermostat selectors. Because this will reduce electrical energy consumption to about $14 \%$.

\section{REFERENCES}

1. Cordoba J., M. Macias, and J. M. Espinosa, 1998, "Studying of the potential savings on energy demand and HVAC energy consumption by using coated glazing for office buildings in Madrid", Energy and Buildings 27, pp. 13-27.

2. Kontoleon K.J., and D.K., Bikas, 2002, "Modeling the influence of glazed openings percentage and type of glazing on the thermal zone behavior", Energy and Buildings 34, pp. 389-399.

3. Askar H., S.D. Probert, and W.J. Batty, 2000, "Windows for buildings in hot arid countries", Applied Energy, 70, pp. 77-101.

4. Sekhar S.C., and K. Toon, 1998, "On the study of energy performance and life cycle cost of smart window", Energy and Buildings 28, pp. 307-316.

5. Al-Sallai K. A. 1998, "Sizing windows to achieve passive cooling, passive heating and day-lighting in hot and arid regions", Renewable Energy 14 (4), pp. 365-371.

6. Al- Rogom F., G.P. Maheshwari, and R.K. Suri, 1999, "Performance of evaporative cooling systems in Kuwait", Kuwait Institut for Scientific Research, Kuwait, Technical report No. KISR 5616,

7. Maheshwari G.P., R.K. Suri, and H.J. Hussain, 2000, "Power ratings of commercial packaged air-conditioners", Kuwait Institut for Scientific Research, Kuwait, Technical report No. KISR 5834.

[8] Al-Marafie A.M., G.P. Maheshwari, and R.K. Suri, 1989, "Energy and power management in air-conditioned buildings in Kuwait", Energy 1989 14(9) 577-62. 
9. Bader Elfahed and Aboelyazeed M. Koluib, 2004, "Improving the performance of A/C package units", Int. Mech. Eng. Conf., Kuwait.

10. Mc. Clellan, C. H.,1988, "Estimating temperature performance for evaporative cooling system in five locations in the untied States", ASHRAE Trans. OT-88-04-1, pp. 1071-1089.

11. Huang Y.J., H.E. Wu, J.W. Hanford, P.L. Chen and H.M., 1991, “On, Energy and comfort performance of evaporative collers for residential buildings in California climates", ASHRAE Trans. IN-91-11-4, pp. 874-881.

12. Sodha M.S., N.K. Bansal, P. Kumar, A. Kumar and M.A.S. Malik, 1986, “Solar passive building", Pergamon Press, Oxford.

13. Singh S.P., T.R. Tulsidasani, R.L. Sawhney, and M.S. Sodha, 1997, "Recent Researches in indirect evaporative cooler v: relative thermal performance of buildings coupled to direct and indirect evaporative cooler", Int. J. Energy Res., Vol. 21, pp. 1413-1423.

14. Tulsidasani T. R., R.L. Sawhney, S.P. Singh, and M.S. Sodha, 1998, "Recent Researches in indirect evaporative cooler III: Optimization of the cooling potential of a room-coupled indirect evaporative cooler", Int. J. Energy Res., Vol. 22, pp. 741-750.

15. Hatamipour M.S., H. Mahiyar and M. Taheri, 2007, "Evaluation of existing cooling systems for reducing cooling power consumption", Energy and Buildings 39 pp. 105112.

16. MCGraw Hill, New York, 1995, “Carrier Air Conditioning Company, Handbook of Air Conditioning System Design"

17. Bejan A., 1978, "General criterion for rating heat - exchanger performance", Int. J. of Heat and Mass Transfer, 21, pp. 655-625.

18. Began A., 1996, "Entropy generation minimization", CRC Press, New York.

19. Bergles A.E., A. R. Blumenkrantz, and J. Taborek, 1974, "Performance evaluation criteria for selection of enhanced heat transfer surfaces", In Proc. Fifth J. heat Transfer Conf. Tokyo. Pp. 239-243.

20. Cowell T.A., 1990, "A general method for the comparison of compact heat transfer surfaces", Journal of Heat Transfer, pp. 288-294.

21. deJong N.C., M.C. Gentry, and A. M. Jacobi, 1997, "An energy -based air side heat exchanger performance evaluation method: application to a condenser", Int. J. of HVAC\&R Research, ASHRAE. 3(3): pp. 185-195.- 